\title{
IRREGULARITIES AND THE MARKET VALUE OF COMPANIES ${ }^{1}$
}

\author{
SÔNIA F. S. SANTOS \\ (iD) https://orcid.org/0000-0001-8640-5313 \\ BRUNO FUNCHAL ${ }^{3}$ \\ (iD) https://orcid.org/0000-0002-8534-3437 \\ SILVANIA N. NOSSA \\ (iD) https://orcid.org/0000-0001-8087-109X
}

To cite this paper: Santos, S. F. S., Funchal, B., \& Nossa, S. N. (2020). Irregularities and the market value of companies. Revista de Administração Mackenzie, 21(6), 1-24. doi:10.1590/1678-6971/ eRAMD200057

Submission: Mar. 19, 2020. Acceptance: Aug. 18, 2020.

1 I thank God, my family, my teachers and advisors and Banco do Brasil S.A

2 Banco do Brasil S/A, Águas Claras, DF, Brazil.

3 Fucape Business School, Vitória, ES, Brazil.

\section{(c) $\mathbf{B Y}$}




\section{ABSTRACT}

Purpose: To investigate the impact of the irregularities under analysis and/or judged in the sanctioning administrative proceedings of the Securities and Exchange Commission on the market value of Brazilian companies. Thus, we used the signaling theory to analyze how stakeholders interpret situations and where the available information is asymmetric and incomplete among market agents.

Originality/value: The study was based on the assumption that the conviction within the scope of the regulatory body can negatively affect the company's reputation and value. Empirical evidence indicates that irregularities affect market sentiment. On the other hand, the company can present a better market value if an effective and efficient corporate governance is established, aligning the interests of stakeholders and management.

Design/methodology/approach: Information was collected with quarterly data covering the period from 2010 to 2018 . Two hypotheses were tested by means of regression analysis in OLS with pooled data, panel - fixed effects and 2SLS.

Findings: The results indicated that the irregularities, in the analyzed period, did not impact the companies' market value in the estimation by MQ2E. We suggest to the chief executive officer (CEO) and the chief financial officer ( $\mathrm{CFO}$ ) that they assess the level of corporate governance of their companies and invest in the search for excellence since the best levels of governance bring a positive signal to the market. The CEO is advised to pay attention to the fact that good governance is not enough to keep companies from being irregular.

\section{KEYWORDS}

Irregularity. Governance. Tobin's Q. B3. Signaling. 


\section{INTRODUCTION}

This research has, as its main goal, to analyze the impact of irregularities in the Administrative Sanctioning Lawsuits (Processos Administrativos Sancionadores [PAS]) on the market value of Brazilian companies listed in B3 as judged between 2010 and 2018 by the Brazilian Securities and Exchange Commission (Comissão de Valores Mobiliários [CVM]) (2019), and as measured by Tobin's $\mathrm{Q}$.

Regarding the informational content of these PAS, studies have been carried out to assess both the market and inverstors' behavior in the face of accounting advertisements (Beaver, 1968; Camargos \& Barbosa, 2007). On the one hand, empirical evidence indicates that corruption, fraud, and irregularities affect market sentiment (Bradley, Gonas, Highfield, \& Roskelley, 2009). On the other, the company can present better market value (Gompers, Ishii, \& Metrick, 2003) if an effective and efficient corporate governance is established, aligning their management with stakeholders' interests (Fama \& Jensen, 1983).

With these aspects presented, the study starts from the assumption that condemnation, within the scope of the regulatory body, can negatively affect the company's reputation and value, as indicated by Davidson, Worrell and Garrison (1988). More precisely, by associating the study with the signaling theory (Spence, 1973), in regards to corporate reputation, it is clear that signals issued by the market, and by companies, can influence their overall reputation and may induce investor behavior (De Carvalho, Silva \& Silva, 2013) by perceiving irregularity as a negative mark on company governance, and as a potential sanction to be applied by the regulator.

This study, however, does not consider actions judged in the judicial sphere, but only in the realm of CVM's PAS (2019). The content of the lawsuits was not analyzed, since it contained information about companies, such as irregularities and the years in which they were judged (CVM, 2019). The results indicate that a relationship between the lawsuits and the market value does not exist. In other words, results indicate that the Brazilian market does not punish companies sued by the CVM.

\section{THEORETICAL FOUNDATIONS}

This section presents the theoretical framework that underlies the present study. First, it should be noted that, according to Yang, Jiao and 
Buckland (2017), reports of high-level financial fraud have made financial statements unreliable. Parmalat, for example, the author of a great corporate success story, presented unreliable statements and, as a consequence, shareholders ended up with nothing (Silva, Sancovschi, Cardozo, \& Condé, 2012). Other financial scandals also resulted in serious repercussions, such as the cases of Enron, WorldCom, and Lehman Brothers (Murcia \& Borba, 2005). As a result, the Sarbanes Oxley Act was created in 2002, in the United States, so that inspection bodies could have a greater power of action and greater rigor in the inspection of capital markets (Yang et al., 2017; Funchal \& Monte - Mor, 2016).

So, while it is important to analyze financial statements, we noticed that, in the literature studying the Brazilian market, there are few studies regarding CVM's PAS. Standing out among the ones already carried out are the studies of: 1. Fusiger, Silva and Carraro (2015), who analyzed the CVM1s audit and PAS; and 2. Borges and Andrade (2019), who analyzed the B3 sectors and CVM's PAS.

Research carried out in other countries perpetuates themes, such as: 1. determinants of financial fraud and corporate governance (Yang et al., 2017); 2. ownership, governance and fraud structure in China (Chen, Firth, Gao, \& Rui, 2006); 3. corporate fraud, systematic risk and shareholder enrichment (Cloninger \& Waller, 2000); 4. closing pressure, executive compensation and corporate fraud in China (Zhou, Zhang, Yang, Su, \& An, 2018); 5. corporate value governance in China (Cheng, Su, Yan, \& Zhao, 2019), in the United States (Brown \& Caylor, 2006; Bhagat \& Bolton, 2019) and in the Gulf (Pillai \& Al-Malkawi 2018).

\subsection{Irregularities: PAS-CVM}

In order to detect systematic manipulative behavior, Armstrong, Jagolinzer and Larcker (2010) analyzed whether the shareholdings and share-based compensation of the chief executive officer (CEO) provided incentives to manipulate the accounting reports, by considering three types of "accounting irregularities". These are: 1 . financial correction; 2. a company accused of accounting manipulation in collective action; and 3. a company accused of accounting manipulation with the Securities and Exchange Commission (SEC). In conclusion, there was no evidence of a positive association between CEO incentives and accounting irregularities.

Along the same line of research, Hennes, Leone and Miller (2008) presented three other criteria to distinguish errors from irregularities: 
1. reformulations using variants of the words "fraud" or "irregularity", in reference to irregularities; 2 . reformulations with investigations related to the SEC or the Department of Justice (DOJ) as irregularities; and 3. the presence or absence of other investigations in the accounting matter is considered.

The disclosure of irregularities, however, varies from one country to the next. In the United States, for example, the SEC issues the Accounting and Auditing Enforcement Releases (AAER), which presents the lawsuits related to accounting misconduct and its impact on the financial statements (Borges $\&$ Andrade, 2019). In China, the Stock Market and Accounting Research Database (CSMAR) presents the lawsuit related to the acquisition of illegal papers, the manipulation of stock prices and fraud in financial statements, among other irregularities. Finally, in Brazil, the Law no. 6385 of 1976, which created the CVM, determined in article 8 , that it would have the competency to: survey; analyze; ascertain, through administrative sanctioning lawsuits, irregularities in relation to the securities market, which may culminate in sanctions; and apply punishments to infringement agents without prejudice to criminal or civil liability.

Borges and Andrade (2019) report that, despite the differences regarding PAS in each country, in Brazil, PAS are similar to the accounting scandals that occur in the United States. The authors analyzed the typology of CVM's PAS, from 1989 to 2016, and concluded that, in general, the financial sector has the highest amount of PAS.

\subsection{Irregularities and governance}

Based on numerous corporate governance failures (Fich \& Shivdasani, 2007), there is a consensus among authors that financial fraud leads to significant losses in valuation for investors (Zhou et al. 2018). Fich and Shivdasani (2007), for example, studied, in the United States, companies facing shareholder class actions alleging financial misrepresentation based on the United States Securities and Exchange Commission Act of 1934. The survey results showed that companies who shared directors with other boards who had been accused of fraud were more likely to face charges of fraud whose losses appeared to result in the stock price due to the bad reputation os these organizations due to the evidence of fraud. Dechow, Sloan and Sweeney (1996) and Rezaee and Kedia (2012) concluded, in their studies, that there is a positive association between bad corporate governance and financial fraud. 
In another manner, other international empirical research has attested to the presence of a positive effect between corporate governance and corporate profitability (Fama \& Jensen, 1983). This is the case made by Koerniadi, Krishnamurti and Tourani-Rad (2014) who, when analyzing corporate governance practices and variation in stock prices and returns, showed that New Zealand companies, when well managed, ceteris paribus, experienced lower risk levels. The results showed that aspects of corporate governance, such as board composition, shareholder rights, and disclosure practices, were associated with lower risk levels.

In the same vein, Fu (2019) concluded that good governance could positively moderate the impact of bad news, such as irregularities, corruption and fraud. In this present paper, there are indications of this result, although without statistical significance.

\subsection{Signaling theory}

Spence's signaling theory (1973) has, as an elementary requirement for its construction, information asymmetry. The economist Spence (1973) used, in his seminal article focused on the construction of the signaling theory, data from the labor market to explain the application of education signaling as a reducing mechanism of information asymmetry in the labor market. In relation to behavior in the stock market, when based on decisions, such as buying, selling or keeping shares (Janiszewski, Carrascoso, Félix, Lagioia, \& Oliveira, 2017), the signaling theory helps explain how stakeholders evaluate and react to a situation in which the available information is irregular, incomplete, and distributed asymmetrically among market users (Spence, 1973).

Eccles and Coleman (1998), for example, observed that there is a positive relationship between the performance of a company and the publication of financial statements at the end of the year. This study also seeks to identify, based on Spence's signaling theory (1973) if, after CVM's disclosure of the irregularities by the PAS, the market responds negatively in its calculation of the company's value.

To this end, we considered that, according to the CVM, the Sanctioning Administrative Process (PAS) is the result of an investigation for which evidence of authorship and materiality relating to any irregularity occurred within the scope of the capital market had been found and resulted in prosecution. The result of the judgment, when in case of conviction, applies the penalties provided for in art. 11 of Law no. 6,385 of 1976, and is available on the CVM website. 


\subsection{Irregularities, governance (IGC) and company value}

As presented in the theoretical framework, this paper connects several strands of literature. The first one focuses on frauds, with many empirical studies, such as that of Aggarwal, Hu and Yang (2014), after the accounting scandals that occurred with Enron and WorldCom in the early 2000s in the United States (Scharff, 2005).

The second one considers the interaction of irregularity with corporate governance, for example, in studies, such as those by Chen et al. (2006) and Borges \& Andrade (2019), who analyze said relationship based on the composition of the board (Yang et al. 2017), agent remuneration (Zhou et al. 2018), and conflict of interest (Fich \& Shivdasani, 2007). There is also literature that refers to fraud and irregularities with the company's performance (Cloninger \& Waller, 2000), and still more, such as Janiszewski et al.'s (2017), which are related to the signaling theory (Spence, 1973).

In Brazil, despite financial and accounting scandals, such as those uncovered by the Operation Lava Jato (the Operation Car Wash), and that of PAS, there are few studies on the irregularity variable (CVM, 2019), governance $(B 3,2019)$ and measured market value by Tobin's $Q$ in the PAS (Tobin, 1969). Yang et al. (2017) and Bhagat and Bolton (2019) also analysed market value after the announcement of the information. In this study, we calculated the Tobin's $\mathrm{Q}$ for the fourth quarter of the fiscal year after the announcement of the lawsuit by the CVM, as the expectation was that the market would penalize companies sued by the CVM, bringing us to the first hypothesis:

- H1: Irregularity, as judged by the CVM, has a negative effect on the involved companies' market value.

What makes this study different is that the irregularity variable is studied (CVM, 2019), through the PAS by CVM, in relation to its impact on the companies' market value. Another difference is to analyze this irregularity (CVM, 2019) including corporate governance variables, such as the corporate governance index (índice de governança corporativa $[\mathrm{IGC}]$ ) $[\mathrm{B} 3,2019)$ and the BIG4. Having done this, the conclusion was that, in the period studied, the PAS (CVM, 2019) infers to causing a negative impact on the market value measured by Tobin's $Q$ and that the irregularity analyzed with IGC indicates that this impact is mitigated. Thus, the second hypothesis is presented:

- H2: The negative impact of irregularities in the market value is mitigated in companies with better governance. 


\section{METHOD}

In order to achieve the research objective, an empirical study was developed with secondary data. The estimation of the studied relationships occurred through an adaptation of the studies by Yang et al. (2017) and Bhagat and Bolton (2019), who verified the relationship between the variables that make up the econometric model - irregularities (CVM, 2019); (IGC) (B3, 2019); market value as measured by Tobin's Q (Tobin, 1969); and control variables. In this study, we follow Yang et al. 's (2017) and Bhagat and Bolton (2019) 's proposition, that is, we work on a level estimation, meaning that we calculate the Tobin's $Q$ for the fourth quarter of the fiscal year after the announcement of the lawsuit by the CVM.

This topic presents information related to the population, sample, and empirical models for estimating the hypotheses. To form the research sample, secondary data was collected from all publicly traded Brazilian companies listed in B3 from 2010 to 2018. This period is justified by the adoption of the International Financial Reporting Standards (IFRS) in Brazil, by the 2007 Law no. 11638, which was widely adopted in 2010, so the accounting data used may have been affected by changes in the accounting model.

The companies' financial accounting data was obtained using the Economatica ${ }^{\circledR}$ software database, on a quarterly basis. The PAS report was found on the CVM website (2019), and, if the company in question was audited by a BIG4 accounting firm (Yang et al., 2017), the information was collected from B3 (2019). The database was entirely manually unified, using data obtained from the Economatica ${ }^{\circledR}$ software, CVM and B3.

In the applied methodology, we used the panel data technique, which conciliates cross-sectional data with time series. For this technique, the estimates were presented by ordinary least squares (OLS), for panel data in pooled and EF, as well as by two stage least squares (2SLS) in pooled, in order to use the variable irregularity as an exogenous instrument for governance.

Before the estimates, we analyzed the data distribution regarding normality and there were no problems in the data. The verified outliers were corrected by the $1 \%$ winsor technique. We perfomed a heteroscedasticity test, and we used the White correction for heteroscedasticity. With regard to univariate analysis (Pearson correlation), as well as the variance inflation factor (VIF) multicollinearity test, there was no multicollinearity problem that compromised the estimation.

In regards to the studied relationships' estimates, we took into account that the most common regression models with panel data are the ones using 
pooled and fixed effects panel (Takahashi, 2016). Our initial approach was to estimate the parameters of econometric models in order to provide evidence on the relationship between irregularity and the market value of firms. Then, the variables BIG4 and IGC were added to analyze their relationship and impact on regression. Finally, the interaction variable (irregularity*igc) was added for a better analysis of the corporate governance aspect.

The tested model is represented by Equation 1 below:

$$
\text { Tobin's } Q_{i t}=\beta_{i}+\psi_{t}+\beta_{1} I_{R R E G}+\beta_{2} I_{i t} C_{i t}+\beta_{3} I R R E G \times I G C_{i t}+\beta_{k} \sum_{k=4}^{6} \text { Controls }_{i t}+\varepsilon_{i t}
$$

According to Wooldridge (2010), the pooled least squares model assumes that the correlation between unobservable characteristics and the regressors is zero. In relation to the PE model, it considers heterogeneity between individuals, allowing each variable to have its own intercept and not vary over time. Thus, any explanatory variable that is constant over time is omitted from the PE model, as is the case with the governance variable (IGC). In order to estimate the effect of governance, and estimate the second hypothesis, the use of pooled is justified, then, with fixed effect for the sector.

The estimation by 2SLS consists of the OLS applied twice. In the first stage, the equation is estimated in a reduced form, calculating the values of the endogenous variable, and then, in the second stage, the equation is estimated simultaneously, through the estimated value of the endogenous variable (Gujarati, 2006). According to Wooldridge (2010), the 2SLS methodology is used to treat endogeneity problems of one or more explanatory variables, such as omission of variables in the model due to unobservable fixed effects, reverse causality, and variables measurement errors.

The model studied in Equation 1, for example, shows a potential reverse causality problem, or simultaneity bias. This occurs when variable $\mathrm{X}$ causes Y or when Y causes X. Regarding this bias, Brown and Caylor (2006) reported in their studies that governance variables can present causes of endogeneity and, taking this into account, we opted to use 2SLS to better examine the robustness of the results.

In addition, in order to meet the assumptions of variables instrumentalization, the variables of corporate governance (IGC) and model irregularity were removed, and the combination of the two series was added: the IGC was used as the endogenous variable, considering that the decision to belong to the IGC improves companies' information and operations and brings benefits that increase the companies' market value, thus being able to produce a bias in the evaluation and vice versa. Irregularity was an exogenous 
variable, used as an instrument, because merely belonging to the IGC does not mean that the company will not commit irregularities. A good candidate for an instrument is one that has a high correlation to the endogenous variable, in this case, IGC, and that is independent of the variable whose behavior we seek to understand, in this case, the Tobin's Q (or $\operatorname{cov}(\varepsilon, \operatorname{IRREG)}=0$ ). The variable irregularity potentially has such characteristics because companies with good governance have good internal controls and are naturally less prone to irregularities, showing a correlation between IGC and IRREG. Likewise, there is no evidence that Tobin's $Q$ is directly influenced by reports of irregularities, which suggests independence between Tobin's $Q$ and IRREG. Therefore, the irregularity variable is a good candidate to be used as an instrument in the 2SLS model and tends to contribute to endogeneity problems traditionally existing in governance variables.

In order to use an instrumental variable, two requirements are applied in linear models: the instrument must be correlated with the endogenous regressor and the instrument cannot be correlated with the error term in the explanatory equation (Wooldridge, 2010).

Considering the combination of the two series and the fact that the estimates of Equation 1 in pooled and fixed effects may possibly produce skewed and inconsistent coefficients, the 2SLS regression model was applied, using Equation 2 for the first stage, as seen below:

$$
I G C_{i t}=\alpha_{i t}+\beta_{1} I R R E G_{i t}+\varepsilon_{i t}
$$

For the second stage, the regression model (3) was applied:

$$
\text { Tobin's } Q_{i t}=\alpha_{i t}+\beta_{1} I G C_{i t}+\beta_{k} \sum_{k=2}^{6} \text { Controls }_{i t}+\varepsilon_{i t}
$$

Regarding the studied variables (dependent, independent, and control), from this point on, the components of Equation 3 are presented. The explained variable, represented in this research by Tobin's Q, according to Nekhili, Nagati, Chtioui, and Rebolledo (2017), can be used as a proxy for companies' market value for four reasons: 1 . measurement based on the stock market price; 2 . because it is market-based, they can better capture the long-term value of activities; 3 . it can be used to compare companies in all sectors because it is not affected by accounting conventions; and, 4. mainly because it is seen as a variable for assessing the effects on reputation, resulting from the various signs made by the company to the market. 
Considering this ratio, Tobin's Q was calculated in a similar way to the research by Nekhili et al. (2017) and Buchanan, Cao and Chen (2018) as the market value of a company's shares (valor de mercado de uma empresa [VMA]) divided by the book value of the total assets (valor contábil do total de ativos [VTA]), a ratio used in the definition of the dependent variable Tobin's Q.

The study's central variable, irregularity (Lennox \& Pittman, 2010), is analyzed through the PAS by the CVM, quarterly, from 2010 to 2018. For this, the variable was treated in a dichotomous way, being 1 for companies that have some irregularity, be it accounting, financial or other, and 0 for the other cases.

This variable was used individually to test Hypothesis 1 . Hypothesis 2 was tested by including the IGC variable (B3, 2019), maintaining its dichotomous form, from which the impact caused by the irregularity, although negative, was expected to be reduced by corporate governance $(B 3,2019)$.

\section{(Figure 3.1)}

\section{MODEL'S CONTROL VARIABLES}

\begin{tabular}{|c|c|c|c|c|}
\hline \multicolumn{5}{|c|}{ Tobin's $Q_{i t}=\beta_{i}+\psi_{t}+\beta_{1} I R R E G_{i t}+\beta_{2} I_{G} C_{i t}+\beta_{3} I R R E G \times I G C_{i t}+\beta_{k} \sum_{k=4}^{6}$ Controls $_{i t}+\varepsilon_{i t}$} \\
\hline Variable & Description & Reference & $\begin{array}{l}\text { Data } \\
\text { source }\end{array}$ & $\begin{array}{l}\text { Expected } \\
\text { signal }\end{array}$ \\
\hline BIG4 (Dummy) & $\begin{array}{l}\text { Assumes value } 1 \text { for } \\
\text { companies that are audited } \\
\text { by BIG4, and value 0, } \\
\text { otherwise }\end{array}$ & $\begin{array}{l}\text { Armstrong et al. (2010), } \\
\text { Yang et al. (2017) and } \\
\text { Cheng et al. (2019) }\end{array}$ & B3 & $(+)$ \\
\hline $\begin{array}{l}\text { Return on } \\
\text { Equity (ROE) }\end{array}$ & $\begin{array}{l}\text { Net income/(equity - net } \\
\text { income) }\end{array}$ & $\begin{array}{l}\text { Malta and Camargos } \\
\text { (2016) }\end{array}$ & Economatica & $(+)$ or $(-)$ \\
\hline Leverage (LEV) & $\begin{array}{l}\text { Total debt divided by total } \\
\text { assets }\end{array}$ & $\begin{array}{l}\text { Malta and Camargos } \\
\text { (2016) }\end{array}$ & Economatica & $(+)$ or $(-)$ \\
\hline Intangible (INT) & $\begin{array}{l}\text { Intangible assets divided } \\
\text { by total assets }\end{array}$ & Nam and Uchida (2017) & Economatica & $(-)$ \\
\hline $\begin{array}{l}\text { Earnings per } \\
\text { share (EPS) }\end{array}$ & $\begin{array}{l}\text { EPS }=\text { Net profit /number } \\
\text { of shares }\end{array}$ & $\begin{array}{l}\text { Bastos, Nakamura, David } \\
\text { and Rotta, (2009) }\end{array}$ & Economatica & $(+)$ \\
\hline Size & Ln (total company assets) & Kuzey and Uyar (2017) & Economatica & $(+)$ \\
\hline
\end{tabular}

Source: Elaborated by the authors.

We selected the IGC (Nascimento, Santos, \& Câmara, 2017; B3, 2019) to represent the main corporate governance variable, as it is an index created 
by B3 that represents a portfolio of companies belonging to the New Market (Novo Mercado - B3's governance segment), to Bovespa's levels 1 and 2, and also because it makes a commitment to provide the best information to the market (B3, 2019). Having been used as a dummy variable, 1 was adopted for companies that belong to the IGC and 0 was adopted in the other cases, behaving either as an explanatory variable or interacting with the study's irregularity variable.

The control variables were inserted into the model according to the determinants of Tobin's Q (Tobin, 1969; Malta \& Camargos, 2016; Bhagat \& Bolton, 2019), to allow the results obtained to be moderated for a greater number of factors.

\section{DATA ANALYSIS}

\subsection{Descriptive statistics}

Figure 4.1.1 presents a summary of the descriptive statistics of the economic variables - dependent, Tobin's $\mathrm{Q}-$, the study control variables (ROE, LEV, INT, EPS and Size), as well as the dummy variables. To minimize the effects of outliers, the dependent variable and control variables were winsorized to $1 \%$ for the first percentile and to $99 \%$ for the last percentile, thus avoiding a distortion in the analysis of the results.

Figure 4.1.1 shows the number of observations for each variable, the average, the standard deviation, the minimum, maximum, the median, as well as the first and third quartiles of the sample.

(Figure 4.1.1)

DESCRIPTIVE STATISTICS OF THE STUDIED VARIABLES

\begin{tabular}{lccccccc}
\hline Variable & Obs no. & Average & Max. & 25\% & $\begin{array}{l}\text { Standard } \\
\text { deviation }\end{array}$ & Median & $75 \%$ \\
\hline QTOBIN_W & 11.633 & 0.880 & 9.025 & 0.013 & 1.337 & 0.469 & 0.945 \\
\hline IRREG & 23.508 & 0.007 & 1.000 & 0.000 & 0.084 & 0.000 & 0.000 \\
\hline IGC & 23.508 & 0.289 & 1.000 & 0.000 & 0.453 & 0.000 & 0.000 \\
\hline BIG4 & 23.508 & 0.407 & 1.000 & 0.000 & 0.429 & 0.000 & 0.000 \\
\hline ROE_W & 14.865 & 0.005 & 0.003 & -0.393 & 0.042 & 0.000 & 0.000 \\
\hline
\end{tabular}




\section{(Figure 4.1 .1 (conclusion))}

DESCRIPTIVE STATISTICS OF THE STUDIED VARIABLES

\begin{tabular}{lrrrrrrr}
\hline Variable & Obs no. & Average & Max. & $25 \%$ & $\begin{array}{l}\text { Standard } \\
\text { deviation }\end{array}$ & Median & $75 \%$ \\
\hline LEV_W & 13.981 & 1.204 & 31.000 & 0.000 & 3.599 & 0.585 & 0.769 \\
\hline INT_W & 12.960 & 125.685 & 789.991 & 0.000 & 194.048 & 18.066 & 186.237 \\
\hline EPS_W & 14.845 & -0.099 & 28.533 & -40.042 & 6.403 & 0.135 & 0.765 \\
\hline SIZE_W & 14.868 & 13.941 & 20.228 & 3.931 & 2.754 & 14.403 & 15.687 \\
\hline
\end{tabular}

Source: Elaborated by the authors.

The average market value shows extreme values, when comparing the minimum and the maximum, with a peak of the maximum value of 9.025. Thus, it is noted that, considering an average market value of 0.880 , only $25 \%$ of the companies have a value greater than 0.945 , showing a significant distance from the median of 0.469 , that is, more than half of the companies are below the average calculated. Regarding the explanatory variables, regarding irregularity, the descriptive statistics show that $0.7 \%$ of the companies have at least one irregularity. Regarding the IGC variable, we noted that $28 \%$ of the observations are in the group belonging to the IGC (Figure 4.1.1).

The ROE variable, which explains the effects of companies' financial performance in relation to Equity (Malta and Camargos, 2016), presents an average result of -0.005 , ranging from a minimum of -0.393 to a maximum of 0.003 . The LEV variable had an average of 1.204 and a median of 0.585 , showing a relevant distance between the average and the median. The INT shows an average of 125,685 , with $25 \%$ of the observations showing a value above 186,237 (Figure 4.1.1).

INT variable, even with winsorization, remained with its values practically unchanged. Regarding the EPS variable, it had a median of 0.135 and a maximum extreme value of 28.533. The SIZE variable showed that the average market value was 13.941 , highlighting that approximately $50 \%$ of the observations have values close to the median, but $25 \%$ of the companies have values above 15.687 , with a maximum value of 20.228 . Finally, analyzing BIG4, which was also a control variable, we observed that $40.78 \%$ of the observations were audited by a BIG4 (Figure 4.1.1).

Lastly, the analysis of the remaining 80 companies, which did not belong to the IGC, shows evidence that only 21 companies were audited by a BIG4; 
also, we found that 51 companies are no longer listed on the B3. The overall total of canceled companies represented $47.70 \%$ of the sample, with companies with a low level of governance responsible for $98 \%$ of the cancellations of companies on the B3 listing.

\subsection{Regression analysis - OLS, fixed effect panel and 2SLS}

Regression analysis was first applied by the OLS with pooled stacked data and EF panel. The study, with regression in 2SLS, was also administered applying the instrumental variable methodology, with the IGC being the instrumentalized endogenous variable and the instrument being the irregularity.

\section{(Figure 4.2.1)}

REGRESSION ANALYSIS - HYPOTHESIS TEST

\begin{tabular}{|c|c|c|c|}
\hline Explanatory variables & Pooled & EF Panel & 2SLS \\
\hline IRREG*IGC & -0.0772289 & -0.275205 & - \\
\hline IRREG & $-0,1928138$ & 0,0061345 & - \\
\hline VI IGC & - & - & 0,9552914 \\
\hline IGC & $0,2608972^{\star \star \star}$ & Omitted & - \\
\hline BIG4 & $0,6474458^{\star \star \star}$ & $0,1535668^{\star \star}$ & 0,0612056 \\
\hline ROE_W & 0.3129874 & 0.7933936 & -1.281526 \\
\hline LEV_W & $0.0223012^{\star \star}$ & 0.0075245 & $0.0856905^{\star \star \star}$ \\
\hline INT_W & $0.0006736^{\star \star \star}$ & -0.0003879 & $0.0003746^{\star *}$ \\
\hline EPS_W & $0.0171899^{\star \star \star}$ & $0.0059701^{\star \star \star}$ & $0.0163914^{\star \star \star}$ \\
\hline SIZE_W & $-0.2777852^{\star \star \star *}$ & $-0.6406686^{\star \star \star}$ & -0.0282834 \\
\hline Sector & Yes & No & Yes \\
\hline Year & Yes & Yes & No \\
\hline Comments & 8923 & 8759 & 8759 \\
\hline F for significance & $65.69^{\star \star \star}$ & $9.16^{\star \star \star}$ & \\
\hline$R^{2}$ & 0.1855 & 0.2221 & \\
\hline
\end{tabular}

Results with significance at * $10 \%$; * $5 \%$ and ${ }^{* *} 1 \%, R^{2}$ from pooled was adjusted $R^{2}, R^{2}$ from EF panel was $R^{2}$ within. 
The pooled OLS confirmed the research hypothesis that corporate governance is shown to be significant, on average, to explain the market value. The hypothesis that the interaction between corporate governance and lawsuits about irregularities would influence market value is not statistically significant. In other words, it was not possible to affirm the results of Fu (2019) that better governance improves the company's value or mitigates the reported negative impact (Figure 4.2.1).

In a second stage of the research, we estimated, in a fixed effects panel that does not allow the analysis of the governance effect in relation to the market value, when the company commits an irregularity, since the IGC is fixed in time and presents a perfect multicollinearity in EF, and therefore is omitted. Because of this, it was not possible to analyze the second hypothesis of the survey by this estimator (Figure 4.2.1). The IGC is statistically significant and positive in regards to the market value, but the fact that the company had been sued by the CVM was not significant. That is, it cannot be said that, in the Brazilian market, companies are punished by the market when they commit fraud to the point of being sued by the CVM. (Figure 4.2.1)

Finally, the results estimated by two stage least squares are presented when a potential endogeneity problem is identified between the variables Tobin's Q and IGC. In addition, due to the possible causal problem, the 2SLS was used as an additional model to assess the robustness of the results to this potential problem. Furthermore, according to Wintoki, Linck and Netter (2012), studies on the relationship between corporate governance mechanisms and business performance are subject to problems of endogeneity, which is why, in this context, an instrumental variable can be used (Wintoki et al. 2012). Thus, as it was already explained in the methodology, the relationship between IGC and irregularity was first verified and the results allow us to use: instrumental variable $=($ ICG $=$ irregularity $)$. In this way, the estimation occurred using instrumental variables to estimate the regressions by 2SLS shown in Figure 4.2.1.

We present some additional details of the estimation that occurred before the estimation with instrumental variables. The irregularity variable was used as an instrument in the first stage regression because, after analyzing the database, we found that there was a total of 109 companies that had 168 lawsuits initiated against them. Of the 110 companies, 29 were part of the IGC, of which 24 were audited by a BIG4 and still committed irregularities. However, only one was canceled, suggesting that the IGC does not prevent the irregularity, but it does, in fact, mitigate the consequences when an irregularity occurs. Thus, the simple fact that a company commits an irregularity 
does not necessarily significantly affect its market value, but an irregularity committed in a company without a high level of governance can have serious consequences for the stakeholders involved.

The instrumental variable in 2SLS showed a positive coefficient, but not statistically significant. When using the variable irregularity as an instrument, the result obtained in the second stage equation did not allow affirmation that good governance positively influences the market value, as it also does not present statistical significance. In the control variables, the highlight was the EPS variable, which presented a positive coefficient with statistical significance in the three estimates (Figure 4.2.1).

\subsection{Results discussion}

The results found in this study suggest that there is no negative impact of the irregularity on the market value. This result is contrary to findings already recorded in the literature, for example, those by Fich and Shivdasani (2007) or Wang, Ashton and Jaafar et al. (2019), who stated that fraud causes great damage to reputation, including reducing the wealth of shareholders of fraudulent companies.

Regarding the IGC variable, which represents the corporate governance variable, there are indications that a high level of governance improves the share value, and these results are aligned with the results found by Cheng et al. (2019).

Concerning irregularity and governance, $\mathrm{Fu}$ (2019) showed in his results that companies associated with people who are indicted in the anti-corruption campaign lose significant value after the accusation announcement. They also concluded that good external governance can positively moderate the short-term impact of these negative events. However, in Brazil, the same cannot be affirmed, as there was an occurrence of irregularity even among companies with a high level of governance.

Referring now to the signaling theory presented to the market, it reveals signs that belonging to the IGC does not mean not having irregularities, but it represents a potential reduction of the impact on the company's value. This result converged to another suggestion of result obtained by Fu (2019), in which corporate governance moderates the impact of negative corporate events, but the results presented for the Brazilian market are not aligned with those of previous studies in other countries, and, because of our results, we cannot say that corporate governance moderates the relationship between irregularity and market value. 
Still on governance linked to irregularity, the result came close to Yang et al. 's (2017) and Zhou et al. 's conclusions (2018), in which, depending on the level of governance, there may or may not be a high contribution to the likelihood of fraud. This is the same as Fich and Shivdsani's (2007) 's understanding, according to which, when they analyzed financial fraud, the board's reputation, and the shareholders' wealth, they concluded that the companies' loss of value by fraud is amplified if they have fragile governance characteristics.

By achieving these results, this paper contributes, in a theoretical and practical manner, to the national literature, to the market, and to the regulatory bodies, with the evaluation of the company's value through important aspects related to the irregularities judged in the PAS (CVM) and in the corporate governance. Our research also contributes by serving as a reference, for the market and for inspection agencies, in creating strategies that reduce or eliminate corporate misconduct, as well as to reduce the market risk, since the estimates suggest that the judgment of the irregularities pointed out in the PAS (CVM) represents negative news for the market and for the involved companies' shareholders. Regarding the effect of corporate governance, represented by the variables IGC (B3, 2019) and BIG4, it appears that good governance is a positive sign, due to the possible reduction of the negative impact of the irregularity in the market value. Lennox and Pittman (2010) concludes, in his study, that the company audited by a BIG4 has a good governance brand, thus reducing the risk of irregularity.

\section{CONCLUSION}

The purpose of the study was to investigate the impact of irregularities (under analysis and or judged in the administrative sanctioning proceedings of the Securities and Exchange Commission) on Brazilian companies' maket value. For that, a model for the hypothesis test was presented empirically.

When analyzing the estimation by OLS, panel with fixed effect and 2SLS, we found that the companies that were sued by CVM were not, on average, penalized by the market. In the control variables, the highlight was the EPS variable, which showed a positive coefficient with statistically significant significance in all estimates.

In the panel estimation, the regressions showed signs that belonging to the governance levels of B3, Novo Mercado, level 1 and level 2 mitigates the negative impact of irregularity in the market value, showing that good governance is positive. In addition, the statistical evidence found in this 
research suggested that the Brazilian market has observed this signaling (Spence, 1973), making it possible to further strengthen this signal through the administrative lawsuit judged and sanctioned by the CVM, since not belonging to a superior level of governance makes the negative impact greater.

In view of the result found here, it can be said that the Brazilian stock market is not punishing companies sued by the CVM. It is also worth mentioning that the content of the irregularity lawsuits judged and sanctioned by the CVM was not evaluated, as well as its link with the judiciary. They were only classified as judged, regardless of the penalty or the lack of it presented in the judgment, even though the companies' performance, such as their market value, could be measured in other ways.

Finally, because the empirical results of this study are one of the first to analyze the impact of irregularity in Brazilian companies, it is suggested that future research analyze the value of the stock return through a study of events, within a window of days and, thus, check the possible impacts on the irregularity judgement's date and what it signals to the market. To the chief executive officer (CEO) and the chief financial officer (CFO), we suggest that they evaluate their companies' corporate governance level and invest in the search for excellence, since the best governance levels bring a positive signal to the market, as the company reduces the risk of irregularities, becomes more transparent, and bolsters its investors' confidence. However, it is recommended that the CEO pays attention to the fact that having good governance is not enough to keep them from being irregular. As for the CVM, it is suggested that the creation of a seal for companies that do not have lawsuits in place, in order to provide greater visibility and further improve the signaling, with a periodic review of this base.

\section{IRREGULARIDADES E O VALOR DE MERCADO DAS EMPRESAS}

\section{$\int$ RESUMO}

Objetivo: Investigar o impacto das irregularidades em análise e/ou julgadas nos processos administrativos sancionadores da Comissão de Valores Mobiliários no valor de mercado das empresas brasileiras. Dessa forma, recorreu-se à teoria da sinalização para analisar como os stakeholders interpretam as situações e em que ponto as informações disponíveis são assimétricas e incompletas entre os agentes de um mercado. 
Originalidade/valor: O estudo partiu do pressuposto de que a condenação no âmbito do órgão regulador pode afetar negativamente a reputação e o valor da empresa. As evidências empíricas indicam que a corrupção, a fraude e a irregularidade afetam o sentimento de mercado. Contudo, a empresa poderá apresentar valor melhor de mercado se houver o estabelecimento de uma governança corporativa eficaz e eficiente, alinhando interesses de stakeholders e na gestão.

Design/metodologia/abordagem: Coletaram-se trimestrais que compreendem o período de 2010 a 2018, e testaram-se duas hipóteses por meio de análise de regressão em mínimos quadrados ordinários (MQO) com dados em pooled e painel de efeitos fixos (EF) e mínimos quadrados em dois estágios (MQ2E).

Resultados: Os resultados indicaram que as irregularidades, no período analisado, não impactaram o valor de mercado das empresas na estimação por MQ2E. Sugerimos ao chief executive officer (CEO) e ao chief financial officer (CFO) que avaliem o nível de governança corporativa de suas empresas e invistam na busca da excelência, uma vez que melhores níveis de governança trazem sinalização positiva ao mercado. É importante que o CEO tenha consciência de que o simples fato de as empresas terem boa governança não é suficiente para afastá-las de irregularidades.

\section{$\int$ PALAVRAS-CHAVE}

Irregularidade. Governança. Q de Tobin. B3. Sinalização.

\section{REFERENCES}

Aggarwal, R., Hu, M., \& Yang, J. (2014). Fraud, market reaction, and role of institutional investors in Chinese listed firms. The Journal of Portfolio Management, 41 (5), 92-109. doi:10.3905/jpm.2015.41.5.092

Armstrong, C. S., Jagolinzer, A. D., \& Larcker, D. F. (2010). Diretor executivo, incentivos patrimoniais e irregularidades contábeis. Journal of Accounting Research, 48(2), 225-271. doi:10.1111/j.1475-679X.2009.00361.x

Bastos, D. D., Nakamura, W. T., David, M., \& Rotta, U. A. S. (2009). A relação entre o retorno das ações e as métricas de desempenho: Evidências empíricas para as companhias abertas no Brasil. REGE - Revista de Gestão, 16(3), 65-79. doi:10.5700/issn.2177-8736.rege.2009.36678 
Beaver, W. H. (1968). The information content of annual earnings announcements. Journal of Accounting Research, 6, 67-92. doi:10.2307/2490070

Bhagat, S., \& Bolton, B. (2019). Corporate governance and firm performance: The sequel. Journal of Corporate Finance, 58, 142-168. doi:10.1016/j. jcorpfin.2019.04.006

Borges, S. R. P., \& Andrade, M. E. M. C. (2019). Empresas listadas na B3. Processos sancionadores da CVM: Em qual setor você aposta? Revista Mineira de Contabilidade, 20(2), 62-75. doi:10.21714/2446-9114RMC2019 v20n1t05

Bradley, D. J., Gonas, J. S., Highfield, M. J., \& Roskelley, K. D. (2009). An examination of IPO secondary market returns. Journal of Corporate Finance, 15(3), 316-330. doi:10.1016/j.jcorpfin.2009.01.003

B3 Brasil Bolsa Balcão (2019). Índice de ações com governança corporativa diferenciada (IGC). Retrieved from http://www.b3.com.br/pt_br/marketdata-e-indices/indices/indices-de-governanca/indice-de-acoes-comgovernanca-corporativa-diferenciada-igc.htm

Brown, L. D., \& Caylor, M. L. (2006). Corporate governance and firm valuation. Journal of Accounting and Public Policy, 25(4), 409-434. doi:10.1016/j. jaccpubpol.2006.05.005

Buchanan, B., Cao, C. X., \& Chen, C. (2018). Corporate social responsibility, firm value, and influential institutional ownership. Journal of Corporate Finance, 52, 73-95. doi:10.1016/j.jcorpfin.2018.07.004

Camargos, M. A. de, \& Barbosa, F. V. (2007). Análise empírica da reação do mercado de capitais brasileiro aos anúncios de fusões e aquisições ocorridos entre 1994 e 2001. RAUSP Management Journal, 42 (4), 468-481. doi:10.15 90/S0080-21072007000400007

Chen, G., Firth, M., Gao, D. N., \& Rui, O. M. (2006). Ownership structure, corporate governance, and fraud: Evidence from China. Journal of Corporate Finance, 12(3), 424-448. doi:10.1016/j.jcorpfin.2005.09.002

Cheng, L. Y., Su, Y. C., Yan, Z., \& Zhao, Y. (2019). Corporate governance and target price accuracy. International Review of Financial Analysis, 64, 93-101. doi:10.1016/j.irfa.2019.05.005.

Cloninger, D. O., \& Waller, E. R. (2000). Corporate fraud, systematic risk, and shareholder enrichment. The Journal of Socio-Economics, 29(2), 189-201. doi:10.1016/S1053-5357(00)00061-5

Comissão de Valores Mobiliários (2019). Processos administrativos. Retrieved from http://www.cvm.gov.br/sancionadores/sancionador.html 
Davidson, W. N., III, Worrell, D. L., \& Garrison, S. H. (1988). Effect of strike activity on firm value. Academy of Management Journal, 31(2), 387-394. doi: $10.5465 / 256554$

De Carvalho, V. G., Silva, J. J., \& Silva, C. A. T. (2013). Divulgação da informação contábil: Influência nas decisões de investimentos em ações. Registro Contábil, 4(2), 36-54.

Dechow, P. M., Sloan, R. G., \& Sweeney, A. P. (1996). Causes and consequences of earnings manipulation: An analysis of firms subject to enforcement actions by the SEC. Contemporary Accounting Research, 13(1), 1-36. doi:10.1111/j.1911-3846.1996.tb00489.x

Eccles, R. G., \& Coleman, I. (1998). Pursuing value: The information reporting gap in the United Kingdom. London: PricewaterhouseCoopers.

Fama, E. F., \& Jensen, M. C. (1983). Separation of ownership and control. The Journal of Law and Economics, 26(2), 301-325. doi:10.1086/467037

Fich, E. M., \& Shivdasani, A. (2007). Financial fraud, director reputation, and shareholder wealth. Journal of Financial Economics, 86(2), 306-336. doi:10.1016/j.jfineco.2006.05.012

$\mathrm{Fu}, \mathrm{Y}$. (2019). The value of corporate governance: Evidence from the Chinese anti-corruption campaign. The North American Journal of Economics and Finance, 47, 461-476. doi:10.1016/j.najef.2018.06.001

Funchal, B., \& Monte-Mor, D. S. (2016). Corporate governance and credit access in Brazil: The Sarbanes-Oxley Act as a natural experiment. Corporate Governance: An International Review, 24(5), 528-547. doi:10.1111/corg. 12151

Fusiger, P., Silva, L. M. da, \& Carraro, W. B. W. H. (2015). Auditoria independente: Principais infrações que acarretam em processo administrativo sancionador pela Comissão de Valores Mobiliários. ConTexto, 15(30), 76-93. Gompers, P., Ishii, J., \& Metrick, A. (2003). Corporate governance and equity prices. Quarterly Journal of Economics, 118(1), 107-156.

Gujarati, D. (2006). Econometria básica. Rio de Janeiro: Campus.

Hennes, K. M., Leone, A. J., \& Miller, B. P. (2008). The importance of distinguishing errors from irregularities in restatement research: The case of restatements and CEO/CFO turnover. The Accounting Review, 83(6), 1487-1519. doi:10.2308/accr.2008.83.6.1487

Janiszewski, V. J., Carrascoso, L. A., Félix, L. A., Júnior, Lagioia, U. C. T., \& Oliveira, M. F. J. (2017). Relação da teoria da sinalização com o desempenho das empresas a partir dos seus indicadores de performance de divulgação voluntária. Revista Contabilidade e Controladoria, 9(2), 93-108. doi:10.53 80/rcc.v9i2.52264 
Koerniadi, H., Krishnamurti, C., \& Tourani-Rad, A. (2014). Corporate governance and risk-taking in New Zealand. Australian Journal of Management, 39(2), 227-245. doi: 10.1177/0312896213478332

Kuzey, C., \& Uyar, A. (2017). Determinants of sustainability reporting and its impact on firm value: Evidence from the emerging market of Turkey. Journal of Cleaner Production, 143, 27-39. doi:10.1016/j.jclepro.2016.12.153

Lei n. 6.404, de 15 de dezembro de 1976 (1976). Dispõe sobre as sociedades por ações. Diário Oficial da União, Brasília, DF. Retrived from http://www. planalto.gov.br/ccivil_03/leis/L6385.htm

Lei n. 6.385, de 7 de dezembro de 1976 (1976). Dispõe sobre o mercado de valores mobiliários e cria a Comissão de Valores Mobiliários. Diário Oficial da União, Brasília, DF. Retrieved from http://www.planalto.gov.br/ccivil_ 03/leis/L6385.htm

Lei n. 11.638, de 28 de dezembro de 2007 (2007). Altera e revoga dispositivos da Lei n. 6.404, de 15 de dezembro de 1976, e da Lei n.6.385, de 7 de dezembro de 1976, e estende às sociedades de grande porte disposições relativas à elaboração e divulgação de demonstrações financeiras. Diário Oficial da União, Brasília, DF. Retrieved from http://www.planalto.gov.br/ ccivil_03/_ato2007-2010/2007/lei/111638.htm

Lennox, C., \& Pittman, J. A. (2010). Big Five audits and accounting fraud. Contemporary Accounting Research, 27(1), 209-247. doi:10.2139/ssrn.11 37829

Malta, T. L., \& Camargos, M. A. de (2016). Variáveis da análise fundamentalista e dinâmica e o retorno acionário de empresas brasileiras entre 2007 e 2014. REGE - Revista de Gestão, 23(1), 52-62. doi:10.1016/j.rege.2015. 09.001

Murcia, F. D. R., \& Borba, J. A. (2005). Quantificando as fraudes contábeis sob duas óticas: Jornais econômicos versus periódicos acadêmicos no período 2001-2004. Cadernos de Controladoria-Controladoria Geral do Município do Rio de Janeiro. Retrieved from http://www. rio.rj.gov.br/cgm

Nam, H., \& Uchida, K. (2017). Trade payables and shareholder wealth: Evidence from North Korean shock on South Korean companies. doi:10.21 39/ssrn.2906322

Nascimento, S. P. do, Santos, R. G. dos, \& da Câmara, M. R. G. da (2017). Governança corporativa: Uma análise entre o IGC e o Ibovespa. Revista Brasileira de Economia de Empresas, 17(2), 55-70. 
Nekhili, M., Nagati, H., Chtioui, T., \& Rebolledo, C. (2017). Divulgação de responsabilidade social corporativa e valor de mercado: Empresas familiares versus não familiares. Journal of Business Research, 77, 41-52. doi:10.1016/j. jbusres.2017.04.001

Pillai, R. \& Al-Malkawi, H. A. N. (2018). On the relationship between corporate governance and firm performance: Evidence from GCC countries. Research in International Business and Finance, 44, 394-410. doi:10.10 16/j. ribaf.2017.07.110

Rezaee, Z., \& Kedia, B. L. (2012). Role of corporate governance participants in preventing and participants in preventing and detecting financial statement fraud. Journal of Forensic $\mathcal{E}$ Investigative Accounting, 4(2), 176-205.

Scharff, M. M. (2005). Understanding WordCom's acoounting fraud? Did group thing play a role? Journal of Leadership \& Organizational Studies, 11 (3), 109-118. doi:10.1177/107179190501100309

Silva, A. H. C., Sancovschi, M., Cardozo, J. S. D. S., \& Condé, R. A. D. (2012). Teoria dos escândalos corporativos: Uma análise comparativa de casos brasileiros e norte-americanos. Revista de Contabilidade do Mestrado em Ciências Contábeis da UERJ, 17(1), 92-108.

Spence, A. M. (1973). Job market signaling. Quarterly Journal of Economics, 87(3), 355-374. doi:10.2307/1882010

Takahashi, F. D. (2016). Impacto da diversidade de gênero do conselho de administração sobre a performance financeira da firma. Retrieved from http://hdl.handle.net/11224/1723.

Tobin, J. (1969). Uma abordagem de equilíbrio geral da teoria monetária. Jornal de Dinheiro, Crédito e Serviços Bancários, 1 (1), 15-29. doi:10.2307/19 91374

Wang, Y., Ashton, J. K., \& Jaafar, A. (2019). Does mutual fund investment influence accounting fraud? Emerging Markets Review, 38, 142-158. doi:10. 1016/j.ememar.2018.12.005

Wintoki, M. B., Linck, J. S., \& Netter, J. M. (2012). Endogeneity and the dynamics of internal corporate governance. Journal of Financial Economics, 105(3), 581-606. doi:10.1016/j.jfineco.2012.03.005

Wooldridge, J. M. (2010). Introdução à econometria: Uma abordagem moderna (4a. ed.). São Paulo: Cengage Learning.

Yang, D., Jiao, H., \& Buckland, R. (2017). The determinants of financial fraud in Chinese firms: Does corporate governance as an institutional innovation matter? Technological Forecasting and Social Change, 125, 309-320. doi:10.1016/j.techfore.2017.06.035 
Zhou, F., Zhang, Z., Yang, J., Su, Y., \& An, Y. (2018). Delisting pressure, executive compensation, and corporate fraud: Evidence from China. PacificBasin Finance Journal, 48, 17-34. doi:10.1016/j.pacfin.2018.01.003

\section{AUTHOR NOTES}

Sônia F. S. Santos, master from the Department of Business, Fucape Business School; Bruno Funchal, Ph.D from the Department of Economics, Getulio Vargas Foundation (FGV); Silvania N. Nossa, Ph.D from the Department of Business, Fucape Business School.

Sônia F. S. Santos is now solutions manager at Banco do Brasil S/A; Bruno Funchal is now full professor of the Department of Business at Fucape Business School; Silvania N. Nossa is now professor of the Department of Business at Fucape Business School.

Correspondence concerning this article should be addressed to Bruno Funchal, Avenida Fernando Ferrari, 1358, Boa Vista, Vitória, Espírito Santo, Brazil, CEP 29075-505.

E-mail: bfunchal@fucape.br

\section{EDITORIAL BOARD}

Editor-in-chief

Gilberto Perez

Associated Editor

Antonio Zoratto Sanvicente

Technical Support

Vitória Batista Santos Silva

\section{EDITORIAL PRODUCTION}

Publishing Coordination

Jéssica Dametta

Layout Designer

Emap

Editorial Intern

Paula Di Sessa Vavlis

Graphic Designer

Libro
Language Editor

Daniel de Almeida Leão 